\title{
Bufotenine is able to block rabies virus infection in BHK-21 cells
}

Hugo Vigerelli ${ }^{1,2}$, Juliana Mozer Sciani ${ }^{1}$, Carlos Jared ${ }^{3}$, Marta Maria Antoniazzi ${ }^{3}$, Graciane Maria Medeiros Caporale ${ }^{2}$, Andréa de Cássia Rodrigues da Silva ${ }^{2}$ and Daniel C Pimenta ${ }^{1 *}$

\begin{abstract}
Background: Rabies is a fatal zoonotic neglected disease that occurs in more than 150 countries, and kills more than 55.000 people every year. It is caused by an enveloped single stranded RNA virus that affects the central nervous system, through an infection initiated by the muscular nicotinic acetylcholine receptor, according to many authors. Alkaloids, such as acetylcholine, are widespread molecules in nature. They are present in numerous biological fluids, including the skin secretion of many amphibians, in which they act (together with proteins, peptides and steroids) as protection agents against predators and/or microorganisms. Among those amphibians that are rich in alkaloids, there is the genus Rhinella.

Methods: Bufotenine was isolated from Rhinela jimi skin secretion after a liquid-liquid partition $\left(\mathrm{H}_{2} \mathrm{O}: \mathrm{CH}_{2} \mathrm{Cl}_{2}\right)$ and reversed phase high-performance liquid chromatography analyses (RP-HPLC). Bufotenine was also extracted from seeds of Anadenanthera colubrina in acetone solution and purified by RP-HPLC, as well. Structural characterization was performed by mass spectrometry and nuclear magnetic resonance analyses. Cytotoxic tests of bufotenine were performed over baby hamster kidney (BHK-21) cells using MTT test. For the antiviral activity, Rabies virus strain Pasteur vaccine (PV) was used on fluorescence inhibition test and fluorescent foci inhibition test, with both simultaneous and time course treatment of the cells with the virus and bufotenine.
\end{abstract}

Results: In the present work we describe the effects of bufotenine, obtained either from toads or plants, that can inhibit the penetration of rabies virus in mammalian cells through an apparent competitive mechanism by the nicotinic acetylcholine receptor. Moreover, this inhibition was dose- and time-dependent, pointing out to a specific mechanism of action.

Conclusions: This work do not present or propose bufotenine as a drug for the treatment of rabies due to the hallucinogen and psychotropic effects of the molecule. However, continued studies in the elucidation of the antiviral mechanism of this molecule, may lead to the choice or development of a tryptamine analogue presenting potential clinical use.

Keywords: Rabies, Rhinella, Bufotenine, Alkaloids, Toxins, Mass spectrometry

\section{Background}

According to the World Health Organization (WHO), rabies is a zoonotic neglected disease that occurs in more than 150 countries and territories, killing more than 55,000 people every year, mostly in Asia and Africa [1]. It is caused by a virus that affects the central nervous system and, once symptoms have developed, is nearly always fatal [2,3]. Different in vitro experiments showed

\footnotetext{
* Correspondence: dcpimenta@butantan.gov.br

'Laboratory of Biochemistry and Biophysics, Butantan Institute, São Paulo, SP, Brazil

Full list of author information is available at the end of the article
}

evidences that some cells receptors, such as the muscular form of the nicotinic acetylcholine receptor ( $\mathrm{nAChR}$ ), are capable of participating on the entry of rabies virus into cells [4-7]. Other molecules - including the p75 neutrophin, the neuronal cell adhesion molecule (NCAM) and glicosides of the cell membrane - are also capable of participating in the entry of rabies virus into cells, maybe involved in different stages of the infection [8]. Conformational studies on an internal tetrapeptide of rabies virus glycoprotein ( $\mathrm{Asn}^{194}{ }^{1} \mathrm{Ser}^{195}-\mathrm{Arg}^{196}$-Gly ${ }^{197}$ ) considered this to be an essential part of the binding site of the virus to the acetylcholine receptor and have demonstrated 
that the side chains of asparagine and arginine can, apparently, mimic the acetylcholine spatial structure, being responsible for binding the virus to the acetylcholine receptor [9].

The skin secretion of some amphibians, on the other hand, is rich in alkaloids [10]. Not only that, but also proteins, peptides, steroids and amines that act as chemical protection agents against predators and/or microorganisms, such as fungi and bacteria $[8,11]$. Among those amphibians that are rich in alkaloids, there is the genus Bufo that was recently split into Bufo in the Old World and Rhinella in the New World [12]. Their secretion contain a large number of alkaloids including bufotenine - a tryptamine alkaloid used as a defense mechanism due to its toxicity that is also found in the Leguminosae family [13-16].

Taking into account that the rabies virus can bind to the nicotinic acetylcholine receptor, and that other alkaloids (nicotine, lobeline, cytisine, anabasine etc.) can also bind to these receptors, the aim of this study was to evaluate the effects of bufotenine as a possible interfering agent in the process of infection of the rabies virus in mammalian cells, using the simplified fluorescent inhibition microtest (SFIMT) and rapid fluorescent focus inhibition test (RFFIT) techniques (with adaptations). Both are serologic tests commonly used in rabies diagnosis that are considered viable tools for the evaluation of new natural compounds as potential antiviral agents.

\section{Methods}

Reagents

All reagents were of analytical grade and were purchased from Sigma Aldrich (USA), unless otherwise stated.

\section{Isolation of bufotenine from Rhinella jimi skin secretion}

The collection and housing of Rhinella jimi specimens were performed under license number 15964-1 from the Brazilian Institute of Environment and Renewable Natural Resources (IBAMA). Skins secretions were collected through mechanical stimulation of the parotoid macroglands. A liquid-liquid partition $\left(\mathrm{H}_{2} \mathrm{O}: \mathrm{CH}_{2} \mathrm{Cl}_{2}\right)$ was performed and the aqueous partition was centrifuged at 4,794 $g$ and the supernatant was analyzed by reversed phase high-performance liquid chromatography (RP-HPLC), using a binary HPLC system (20A Prominence, Shimadzu Co, Japan), coupled to a $\mathrm{C} 18$ column $\left(\mathrm{ACE}^{\circ}, 250 \mathrm{~mm} \times 7.75 \mathrm{~mm}\right)$. The mobile phase consisted of solvent $A\left[\mathrm{H}_{2} \mathrm{O}\right.$ : trifluoroacetic acid (TFA); 1000:1] and solvent B [acetonitrile (ACN): $\mathrm{H}_{2} \mathrm{O}: \mathrm{TFA}$; 900:100:1] with a linear gradient of B over A (10\% to $70 \%)$ in 35 minutes, at a constant flow rate of $1.7 \mathrm{~mL} \cdot \mathrm{min}^{-1}$ and monitored by UV absorbance at $214 \mathrm{~nm}$. Fractions were manually collected and submitted to mass spectrometry (MS and MS $^{2}$ ESI-IT-TOF) analyses. The fraction containing bufotenine was then purified using a C18 column $\left(\mathrm{ACE}^{\oplus}, 250 \mathrm{~mm} \times 4.6 \mathrm{~mm}\right.$ ), with a linear gradient of $\mathrm{B}$ over A $13 \%$ to $15 \%$ in 15 minutes, at a constant flow rate of $1.1 \mathrm{~mL} \cdot \mathrm{min}^{-1}$, at $4^{\circ} \mathrm{C}$, monitored by UV absorbance at $214 \mathrm{~nm}$. Bufotenine peak was manually collected, dried and submitted to ${ }^{1} \mathrm{H}$-NMR spectroscopic analyses and/or biologic assays.

\section{Isolation of bufotenine from Anadenanthera colubrine seeds}

Since bufotenine is a long and well known alkaloid that can be also obtained from other biological sources, such as plants, we chose to purify this molecule from Anadenanthera colubrina seeds, which contain up to $2 \%$ of the seed dry weight in bufotenine. The seeds were obtained from the legitimate supplier Arbocenter Comércio de Sementes Ltda, Birigui, São Paulo (batch 0019), Brazil. The extraction of bufotenine was performed as described by Stromberg [16], with modifications. Twenty grams of seeds were powdered and subsequently deionized $\mathrm{H}_{2} \mathrm{O}$ and $5 \mathrm{~g}$ of sodium carbonate $\left(\mathrm{Na}_{2} \mathrm{CO}_{3}\right)$ were added until a uniform mixture was obtained. This solution was then lyophilized and ressuspended in $50 \mathrm{~mL}$ of acetone $\left(\mathrm{CH}_{3} \mathrm{COCH}_{3}\right)$. This extract was filtered and concentrated in a rotavapor system, following RP-HPLC analysis, in a C18 column $\left(\mathrm{ACE}^{\circ}, 250 \mathrm{~mm} \times 4.6 \mathrm{~mm}\right.$ ), with a linear gradient of $\mathrm{B}$ over A $0 \%$ to $100 \%$ in 20 minutes, at a constant flow rate of $1 \mathrm{~mL} / \mathrm{min}$ and monitored by UV absorbance at $214 \mathrm{~nm}$. Bufotenine peak was manually collected and dried for mass spectrometry and biologic assays.

\section{Mass spectrometry}

Previously dried samples were dissolved into 50\% ACN with $0.5 \%$ formic acid for MS and/or $\mathrm{MS}^{2}$ analyses in an ESI-IT-TOF mass spectrometer system (Shimadzu Co., Japan). Typically, $3 \mu \mathrm{L}$ of samples were manually injected in a Rheodyne injector under a constant flow of $50 \mu \mathrm{L} / \mathrm{min}$. The interface voltage used was $4.5 \mathrm{kV}$ and detector voltage, $1.76 \mathrm{kV}$, with source temperature of $200^{\circ} \mathrm{C}$. Data were acquired under positive mode and instrument control, data acquisition and processing were performed by the LCMS solution software (Shimadzu Co., Japan).

\section{NMR analyses}

NMR screening was used to confirm the bufotenine structure from Rhinella jimi skin secretion. ${ }^{1} \mathrm{H}$ NMR spectra were recorded on Bruker $500 \mathrm{MHz}$ spectrometer (Bruker Co., Germany), with samples diluted in deuterated chloroform and achievement of 128 scans. The results were processed in TopSpin 1.3 software (Bruker Co., Germany).

\section{Cells and viruses}

Baby hamster kidney (BHK-21) cells (ATCC ${ }^{\circ}$ CCL - 100) were cultured in Eagle's minimum essential medium, supplemented with $10 \%$ fetal bovine serum (MEM-10), at $37^{\circ} \mathrm{C}$ under a humidified $5 \% \mathrm{CO}_{2}$ atmosphere until the formation 
of the cell monolayer. Rabies virus strain Pasteur vaccine (PV), from Pasteur Institute, Brazil, was used to determine the antiviral activity of bufotenine. The titers were determined by plate assay in BHK-21 cells and expressed as $100 \%$ infecting dose in cell culture (IDCC100) and $50 \%$ focus-forming dose (FFD50) as described by Batista et al. [17].

\section{Cytotoxicity assay}

The cytotoxicity evaluation of bufotenine was performed by MTT [3-(4,5-dimethylthiazol-2-yl)-2,5-diphenyltetrazolium bromide] method, according to Takeuchi et al. [18] and Mosmann [19], with modifications. Briefly, BHK-21 cells $\left(5 \times 10^{4}\right.$ cells/well) were deposited in 96-well tissue culture microtiter plates with $50 \mu \mathrm{L}$ of different bufotenine concentrations diluted in MEM-10. For positive control of citotoxicity dimethyl sulfoxid (DMSO) 20\% was used and the negative control was MEM-10 alone. After 24 hours at $37^{\circ} \mathrm{C}$, under a humidified $5 \% \mathrm{CO}_{2}$ atmosphere, the medium was removed and $50 \mu \mathrm{L}$ of MTT (Sigma $1 \mathrm{mg} /$ $\mathrm{mL}$ ) solution, prepared in MEM-10, was added to each well and the plates were incubated once more for four hours. After incubation, the MTT solution was removed and 100 $\mu \mathrm{L}$ of dimethyl sulfoxide (DMSO) were added to each well to solubilize the formazan crystals. After gently shaking the plates, the crystals were completely dissolved, and the absorbances were measured by using a spectrophotometer (Molecular Devices ${ }^{\circ}$, SpectraMax M2) at $540 \mathrm{~nm}$. The $\mathrm{CC}_{50}$ was defined as the cytotoxic concentration of bufotenine that reduced the absorbance of treated cells to $50 \%$ when compared to the control.

\section{Antiviral activity}

Rabies virus does not cause cytopathic effects in cells cultured in vitro, being necessary some kind of additional test to monitor cell infection, such as tests with antibodies bound to fluorescent substances [20]. For this reason, we choose these two tests adapted from commonly serological tests used for antirabies virus titration, being the fluorescence inhibition a qualitative test, for a better visualization of both the infection and its inhibition, and the fluorescence focus inhibition comprises a quantitative test, used for the statistical analyses.

\section{Fluorescence inhibition test}

This test was based on simplified fluorescent inhibition microtest (SFIMT), acording to Favoretto et al. [21], with modifications. Briefly, $50 \mu \mathrm{L}$ of BHK- 21 cells $\left(5 \times 10^{4}\right.$ cells/ well) were deposited on 96-well tissue culture microtiter plates with $50 \mu \mathrm{L}$ of each bufotenine dose (from 0.5 to 4 $\mathrm{mg} / \mathrm{mL}$ ) and $50 \mu \mathrm{L}$ of PV virus previously diluted at 1:100 (IDCC100). As negative inhibition control, only $50 \mu \mathrm{L}$ of MEM-10 was added to the cells and as positive inhibition control ketamine was used (Dopalen ${ }^{\bullet}, 23.4 \mu \mathrm{M}$ ), according to Lockhart et al. [22]. After a 24-hour period of incubation at $37^{\circ} \mathrm{C}$ under a humidified $5 \% \mathrm{CO}_{2}$ atmosphere, the medium was removed by suction from all wells and the microplates were cooled on ice. The cells were fixed by adding acetone $80 \%$ in water (kept at $-20^{\circ} \mathrm{C}$ ). After 15 minutes, the plates were emptied by inversion and dried at $37^{\circ} \mathrm{C}$ according to Smith et al. [23] and Chaves et al. [24]. The staining was carried out by adding $40 \mu \mathrm{L}$ of an optimal dilution of the antirabies fluorescent conjugate [25]. After one hour of incubation, the microtiter plates were washed by immersion in PBS and then in distilled water. The microtiter plates reading was performed in inverted fluorescence microscope (Leica DMIL, 100× magnification) in a qualitative manner based on the fluorescence inhibition compared to negative and positive controls, where there are $100 \%$ and $0 \%$ of fluorescence, respectively.

\section{Fluorescent focus inhibition test}

This test was based on rapid fluorescent focus inhibition test (RFFIT) acording to Smith et al. [23], adapted to microtiter plates as described by Chaves et al. [24], with modifications. Briefly, $100 \mu \mathrm{L}$ of BHK-21 cells $\left(2.5 \times 10^{4}\right.$ cells/ well) were deposited on 96-well tissue culture microtiter plates containing different bufotenine doses (3.9, 1.95, 0.97 and $0.48 \mathrm{mg} / \mathrm{mL}$ ), and $50 \mu \mathrm{L}$ of PV virus previously diluted at thirty-fold the FFD50 value. As negative inhibition control, only $50 \mu \mathrm{L}$ of MEM-10 was added to the cells and as positive inhibition control ketamine was used (Dopalen ${ }^{\circ}$, $23.4 \mu \mathrm{M})$. After a 20 -hour period of incubation at $37^{\circ} \mathrm{C}$ under a humidified $5 \% \mathrm{CO}_{2}$ atmosphere, the medium was removed by suction from all wells. The procedures of cells fixation and staining were the same described in "Fluorescence inhibition test" section. The microtiter plates reading was quantitatively performed in inverted fluorescence microscope (Leica DMIL, 200× magnification), where each field with fluorescence were counted, being 0 the minimum (positive control) and 18 the maximum (negative control) number of infected fields. The $\mathrm{IC}_{50}$ was defined as the inhibition concentration of bufotenine that reduced the number of fields with fluorescent foci to $50 \%$ when compared with the negative control.

\section{Time course study}

The time course effect of bufotenine was examined on PV virus with two minor modifications of the fluorescent focus inhibition test. First, to test a possible "protector effect", bufotenine was added in different times (1, 3 and 6 hours), prior to the addition of the virus and, secondly, to test a possible "treatment effect", bufotenine was added in different times (1, 3 and 6 hours), after incubation of cells and PV virus. All the other procedures were the same as described in "Fluorescent focus inhibition test" section. 


\section{Data analysis}

The $50 \%$ cytotoxic $\left(\mathrm{CC}_{50}\right)$ and inhibition $\left(\mathrm{IC}_{50}\right)$ concentrations were calculated from concentration-effect curves after linear regression analysis. The results represent the mean \pm standard error of the mean values of two different experiments (triplicates).

\section{Results}

RP-HPLC and mass spectrometry analysis

RP-HPLC analysis of the aqueous partition of Rhinela jimi skin secretion showed the presence of five major HPLC peaks (Figure 1A). MS analysis showed that fraction 3 contained the following $\mathrm{m} / \mathrm{z}$ values: 205, 219 and 160 (Figure 1B). Comparing the $\mathrm{MS}^{2}$ analysis with already published data by McClean et al. [26] (Figure 1C), it was possible to characterize the two indole alkaloids contained in this fraction: the $205 \mathrm{~m} / \mathrm{z}$ correspond to N',N'-dimethyl 5-hydroxytryptamione (bufotenine) and $219 \mathrm{~m} / \mathrm{z}$ correspond to N,N'N'N-trimethyl 5-hydroxytryptamine (5-HTQ). The $160 \mathrm{~m} / \mathrm{z}$ ion is a spontaneous fragmentation of both alkaloids, which also appears on $\mathrm{MS}^{2}$ profile (Additional file 1: Figure S1). This two compounds were separated by RP-HPLC yielding pure bufotenine (Additional file 2: Figure S2), as confirmed by NMR analyses (Additional file 3: Figure S3). Bufotenine from Anadenanthera colubrina seeds were purified only after one chromatographic step, following the acetone extract, being the major peak on the RPHPLC chromatogram and appearing pure on mass spectrometric analyses (Additional file 4: Figure S4).

\section{Cytotoxicity effect on viability of BHK-21 cells}

The $3.9 \mathrm{mg} / \mathrm{mL}$ dose of $R$. jimi bufotenine used on the virologic tests presented statistically significant cytotoxic effects on the viability of BHK-21 cells ( $66 \%$ of viable cells) when compared to the negative (cells + MEM-10) and positive controls (cells + DMSO 20\%) (Additional file 5: Figure S5). Subsequent assays were performed with the seeds bufotenine, due to the high availability. In the MTT test (Additional file 6: Figure S6), it was possible to determine the $\mathrm{CC}_{50}$ value $(7.6 \mathrm{mg} / \mathrm{mL})$.

\section{Antiviral activity}

- Fluorescence inhibition test

Bufotenine was able to inhibit the infection significantly, showing dose-response effect when tested at a concentration of 0.5 to $3 \mathrm{mg} / \mathrm{mL}$ (Figure 2).

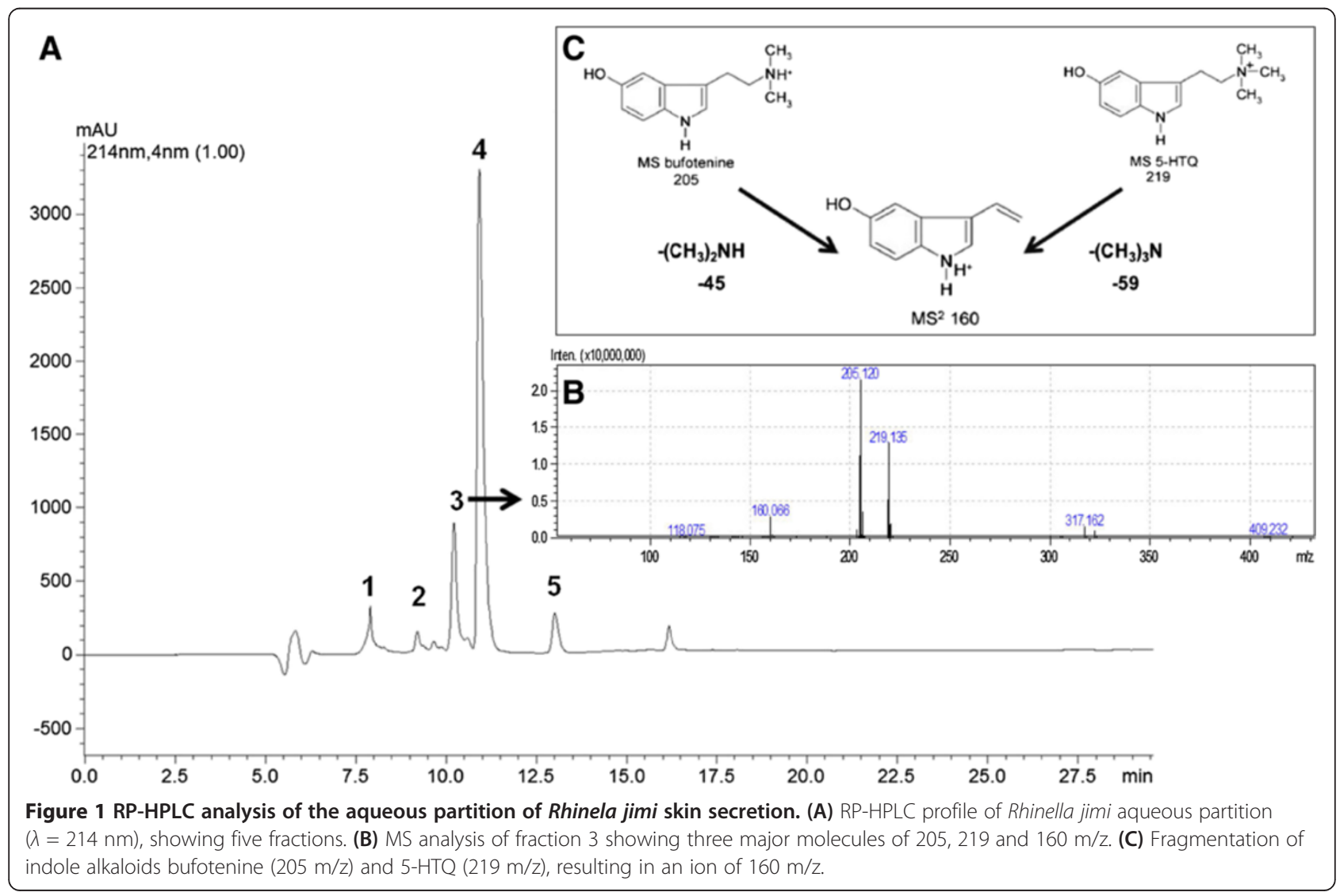



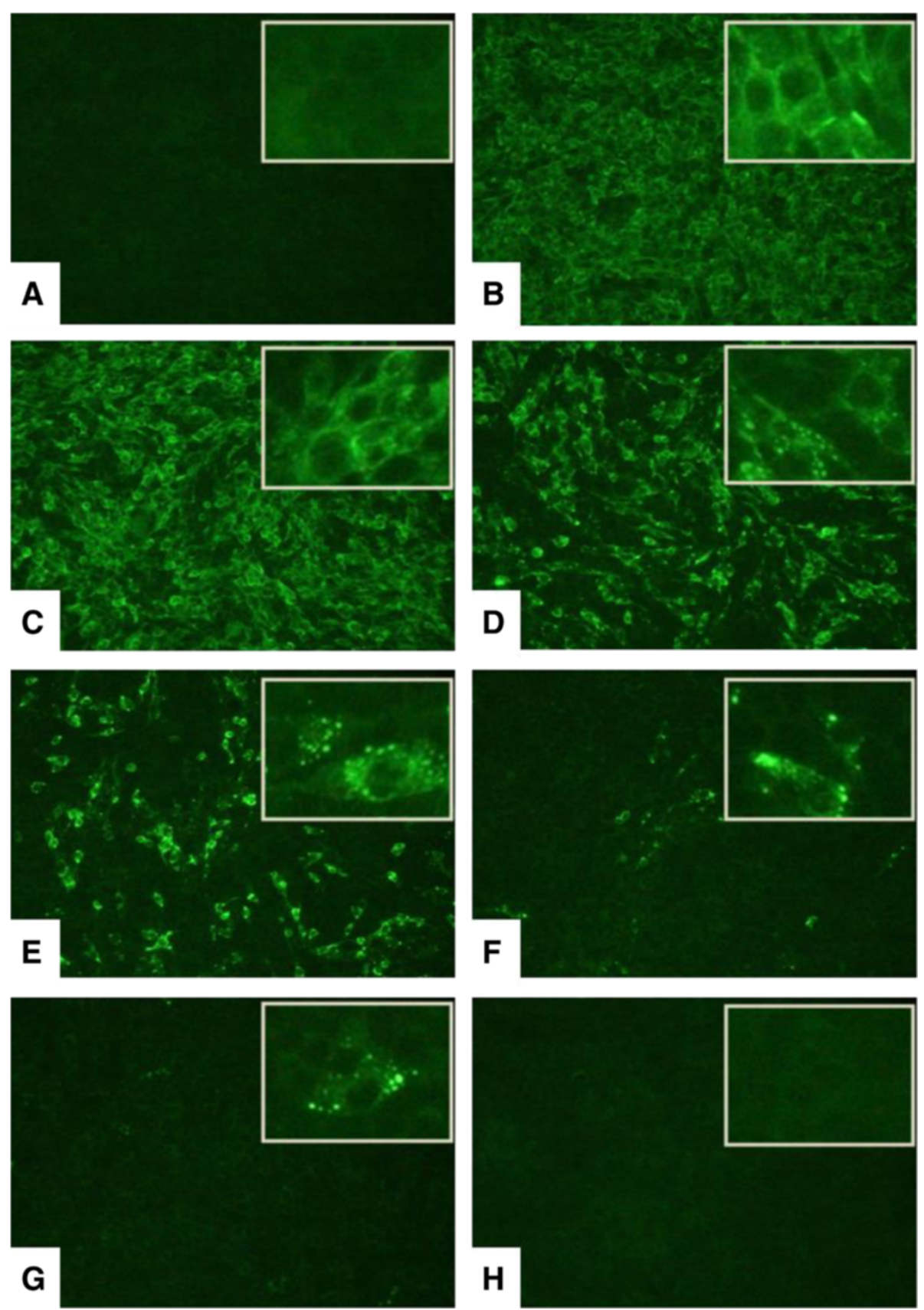

Figure 2 Effects of bufotenine from Anadenanthera colubrine on fluorescence inhibition test. (A) positive inhibition control (ketamine); (B) negative control (cells + MEM-10); bufotenine concentrations: (C) $0.5 \mathrm{mg} / \mathrm{mL}$, (D) $1.0 \mathrm{mg} / \mathrm{mL}$, (E) $1.5 \mathrm{mg} / \mathrm{mL}$, (F) $2.0 \mathrm{mg} / \mathrm{mL}$, (G) $2.5 \mathrm{mg} / \mathrm{mL}$, (H) $3.0 \mathrm{mg} / \mathrm{mL}$. Magnification 100x. Insert magnification 200 x.

- Fluorescent focus inhibition test

Bufotenine was able to inhibit $100 \%$ of the infection at $3.9 \mathrm{mg} \cdot \mathrm{mL}^{-1}$. It was also possible to observe the doseresponse effect. Moreover, there was a time course dependency of the effect regarding the moment of PV virus administration, being bufotenine most effective when added along with the cells and PV virus (time 0, Figure 3).
On the other hand, when bufotenine was administered over the time, the molecule was unable to inhibit the infection, regardless of the tested concentration, from one hour onwards (Figure 4). After testing different bufotenine concentrations in the most effective conditions used in the time course study (time 0 ), it was possible to determine the $\mathrm{IC}_{50}$ value of $(1.57 \pm 0.03)$ mg.mL $L^{-1}$ (Figure 5). 


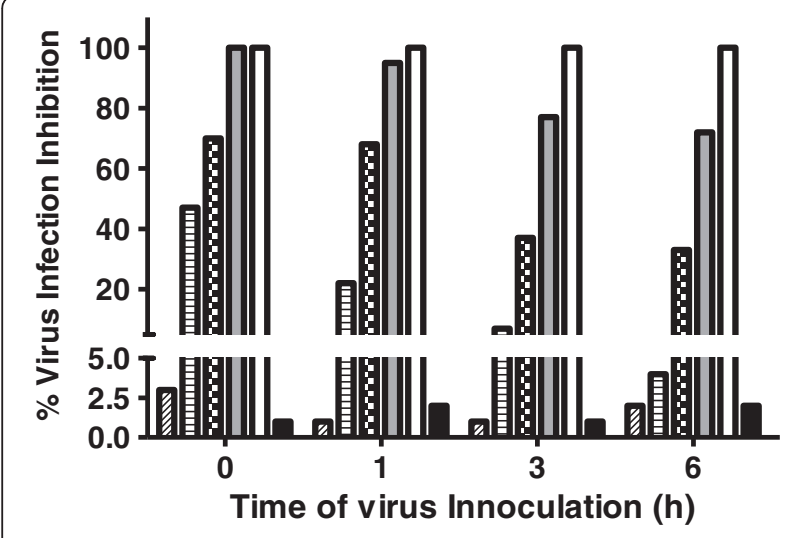

Figure $3 \mathrm{PV}$ virus inhibition effect of bufotenine on fluorescent focus inhibition test, at different times adding PV virus (0, 1, 3 and 6 hours), compared with negative (cells + MEM-10) and positive (ketamine) controls (black and white columns, respectively). Bufotenine concentrations: $3.9 \mathrm{mg} / \mathrm{mL}$ (gray columns), $1.95 \mathrm{mg} / \mathrm{mL}$ (checkered columns), $0.97 \mathrm{mg} / \mathrm{mL}$ (striped columns) and $0.48 \mathrm{mg} / \mathrm{mL}$ (diagonally striped columns).

\section{Discussion}

Although bufotenine was isolated "only" in 1920, shamans and mystics have been employing toads' skin secretions since ancient times as entheogens, which means "generating the divine within" [27]. The chemical structure elucidation was published in 1934 by the group of the chemist Heinrich Otto Wieland and one can observe that the molecule is related to psilocin and dimethyltryptamine (DMT), which are known hallucinogens, as well to the neurotransmitter serotonin [28]. Another early report on the molecule is the documentation of its toxicity, by the

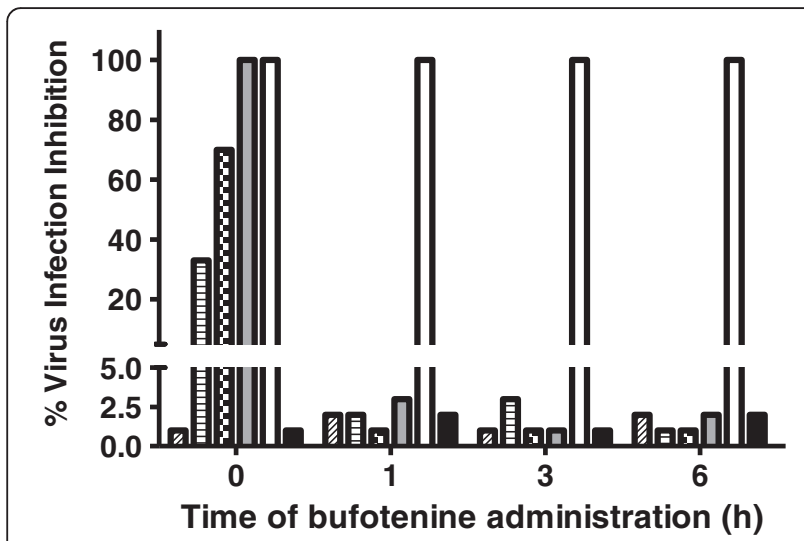

Figure $4 \mathrm{PV}$ virus inhibition effect of bufotenine added in different times (0, 1, 3 and 6 hours) on fluorescent focus inhibition test, compared with negative (cells + MEM-10) and positive $\mathrm{x}$ (ketamine) controls (black and white columns, respectively). Bufotenine concentrations: $3.9 \mathrm{mg} / \mathrm{mL}$ (gray columns), $1.95 \mathrm{mg} / \mathrm{mL}$ (checkered columns), $0.97 \mathrm{mg} / \mathrm{mL}$ (striped columns) and $0.48 \mathrm{mg} / \mathrm{mL}$ (diagonally striped columns).

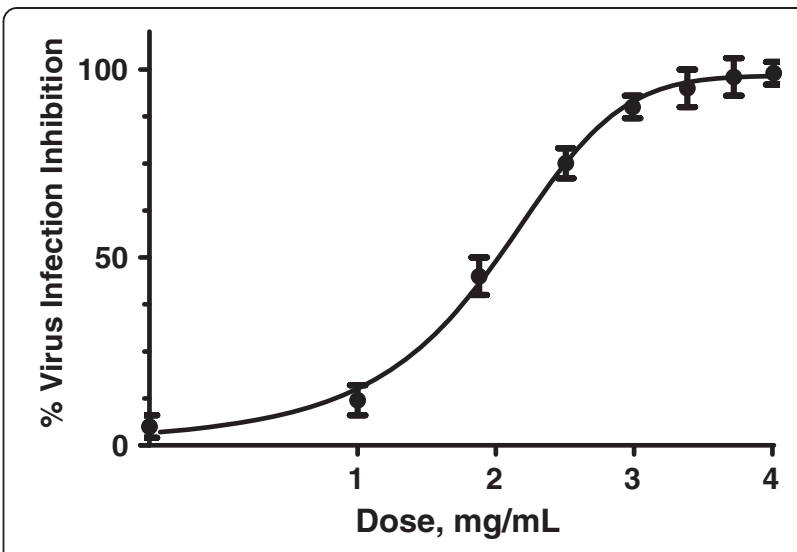

Figure $5 \mathrm{PV}$ virus inhibition percentage of different bufotenine concentrations on fluorescent focus inhibition test compared with negative (cells + MEM-10) and positive (ketamine) controls.

roman poet Decimus Junius Juvenalis (60-128 AD) in the first century.

In this work, we describe bufotenine as an inhibitor of rabies virus penetration in mammal cells. Initial bufotenine isolation and characterization was performed from the skin secretion of the toad $R$. jimi based on biological effectdriven assays, as previously done by the authors [13,29-31]. After initial molecular identification and characterization, we have opted for obtaining this molecule from a more abundant source, so the seeds of Anadenanthera colubrina were chosen, according to early reports on the isolation of this alkaloid of Anadenanthera genus [16].

Bufotenine has been purified, described and synthesized many years ago [32-34]. However, the original isolation process includes several steps of extraction, filtering, partitioning and $\mathrm{pH}$ adjustments [16]. In our work, on the other hand, we were able to demonstrate that the use of chromatographic techniques allows for greater efficiency in the purification of this molecule. Moreover, the association with mass spectrometry analyses allow further evaluation of the purity degree, as well as molecular identity confirmation, for the subsequent biological assays. From the toad skin secretion, pure bufotenine could be obtained after two chromatographic steps, and from the seeds, bufotenine was purified after acetone extraction employing only one chromatographic step, which increased the efficiency and the yield in the obtainment of the pure molecule.

There are recent described effects of hydroalcoholic extracts of different parts of A. colubrina, such as antiinflammatory and peripheral antinociceptive activities in rodent models, antimicrobial (anti-Staphylococcus) and cutaneous wound healing in rats, among others [35-37]. However, these reports describe biological effects of extracts rather than pure molecules. Although the toxic and hallucinogens effects of bufotenine are widely discussed and studied, no reports about its antiviral activity are known to the best of our knowledge [38-40]. 
Among the possible described mechanisms of rabies virus penetration known (or postulated), the bufotenine inhibition of rabies virus infection observed in this study appears to be related to the competition to the cells' receptors, since it could only be observed when simultaneous administration of bufotenine and PV virus was performed (Figure 4). However, the elucidation of this mechanism depends on electrophysiological and/or patch clamp experiments to be performed in the future.

Numerous authors have described that there are highaffinity receptors at host cells specific for rabies virus, which include AChR - and/or associated molecules - that act as receptors. Although it was not possible to unequivocally demonstrate that the inhibitory effect of bufotenine was mediated by its binding to the acetylcholine receptor, the results of this work open important perspectives in the study of the mechanism of action of bufotenine, as well as the elucidation of the mechanisms of the virus pathogenicity. Altogether, our data may aid in the development of $2^{\text {nd }}$ generation active molecules, since rabies is still a disease with no cure prognosis and it kills, every year, thousands of people around the world [1]. Furthermore, bufotenine is cytotoxic, so medicinal chemistry and lead optimization will be required.

\section{Conclusions}

This work do not present or propose bufotenine as a drug for the treatment of rabies for several reasons, including the hallucinogen and psychotropic effects of the molecule. However, continued studies in the elucidation of the antiviral mechanism of this molecule may lead to the choice or development of a tryptamine analogue presenting potential clinical use. These tryptophan derived alkaloids are very interesting building blocks in organic chemistry syntheses [41]. Our next goal would be to evaluate such analogues as possible inhibitors of the viral infection, targeting the dissociation of toxic and psychotropic effects from the antiviral effect.

\section{Ethics committee approval}

The collection and housing of Rhinella jimi specimens were performed under license number 15964-1 from the Brazilian Institute of Environment and Renewable Natural Resources (IBAMA).

\section{Additional files}

Additional file 1: Figure S1. ESI-TT-TOF $M^{2}$ fragmentation profile of (A) $\mathrm{m} / \mathrm{z} 205$ (bufotenine) and (B) m/z 219 ( $\mathrm{N}^{\prime}, \mathrm{N}^{\prime}, \mathrm{N}^{\prime}$-trimethyl 5-hydroxytryptamine [5HTQ]) molecules. Note the common $\mathrm{m} / \mathrm{z} 160$ ion.

Additional file 2: Figure S2. Figure showing (A) C18-RP-HPLC profile of the separation of (B) bufotenine and (C) $5 \mathrm{HTQ}$, at $4^{\circ} \mathrm{C}$.

Additional file 3: Figure S3. Interpretation and annotation of ${ }^{1} \mathrm{H}-\mathrm{NMR}$ spectrum of bufotenine purified from $R$. jimi skin secretion.
Additional file 4: Figure S4. Figure showing (A) ESIIT-TOF MS profile of bufotenine purified from A. colubrine seeds, as represented by (B) the RP-HPLC profile.

Additional file 5: Figure S5. Cytotoxicity evaluation of bufotenine, as assayed at the most effective antiviral dose.

Additional file 6: Figure S6. Percentage of viable cells after treatment with different bufotenine concentrations compared with negative (cells + MEM-10) and positive (DMSO 20\%) controls.

\section{Competing interests}

The authors declare that there are no competing interests.

\section{Authors' contributions}

All authors participated in the design, interpretation and analysis of data, and review of the manuscript. CJ and MMA were responsible for the collection of toads and obtainment of the skin secretion. HV, JMS and DCP conducted biochemical experiments and wrote the manuscript. HV, GMMC and ACRS conducted the cytotoxicity and antiviral experiments. All authors read and approved the final manuscript.

\section{Acknowledgements}

The authors would like to thank FAPESP, CNPq, CAPES and INCT-Tox for their funding of this research. Moreover, DCP is a CNPq fellow researcher.

\section{Author details}

'Laboratory of Biochemistry and Biophysics, Butantan Institute, São Paulo, SP, Brazil. ${ }^{2}$ Laboratory of Serology, Pasteur Institute, São Paulo, SP, Brazil.

${ }^{3}$ Laboratory of Cell Biology, Butantan Institute, São Paulo, SP, Brazil.

Received: 12 June 2014 Accepted: 6 October 2014

Published: 13 October 2014

\section{References}

1. World Health Organization: Rabies fact sheet No 99. [updated September 2014]. http://www.who.int/mediacentre/factsheets/fs099/en/ (Acessed: September 2014).

2. Consales CA, Bolzan VL: Rabies review: immunopathology, clinical aspects and treatment. J Venom Anim Toxins incl Trop Dis 2007, 13(1):5-38. http:// dx.doi.org/10.1590/S1678-91992007000100002.

3. Brandão PE: On the interference of clinical outcome on rabies transmission and perpetuation. J Venom Anim Toxins ind Trop Dis 2009, 15(2):190-203. http:// dx.doi.org/10.1590/S1678-91992009000200003.

4. Watson HD, Tignor GH, Smith AL: Entry of rabies virus into the peripheral nerves of mice. J Gen Virol 1981, 56(Pt 2):372-382.

5. Lentz TL, Burrage TG, Smith AL, Crick J, Tignor GH: Is the acetylcholine receptor a rabies virus receptor? Science 1982, 215(4529):182-184.

6. Burrage $T G$, Tignor GH, Smith AL: Rabies virus binding at neuromuscular junctions. Virus Res 1985, 2(3):273-389.

7. Lewis $P, F u$ Y, Lentz TL: Rabies virus entry at the neuromuscular junction in nerve-muscle cocultures. Muscle Nerve 2000, 23(5):720-730.

8. Lafon M: Rabies virus receptors. J Neurovirol 2005, 11(1):82-87.

9. Rustici M, Bracci L, Lozzi L, Neri P, Santucci A, Soldani P, Spreafico A, Niccolai $\mathrm{N}$ : A model of the rabies virus glycoprotein active site. Biopolymers 1993, 33(6):961-969

10. Maciel NM, Schwartz CA, Rodrigues Pires Júnior O, Sebben A, Castro MS, Sousa MV, Fontes W, Ferroni Schwartz EN: Composition of indolealkylamines of Bufo rubescens cutaneous secretions compared to six other Brazilian bufonids with phylogenetic implications. Comp Biochem Physiol B Biochem Mol Biol 2003, 134(4):641-649.

11. Daly JW, Highet RJ, Myers CW: Occurrence of skin alkaloids in nondendrobatid frogs from Brazil (Bufonidae), Australia (Myobatrachidae) and Madagascar (Mantellinae). Toxicon 1984, 22(6):905-919.

12. Duellman WE, Trueb L: Biology of Amphibians. New York: McGraw-Hill; 1996

13. Sciani JM, Angeli CB, Antoniazzi MM, Jared C, Pimenta DC: Differences and similarities among parotoid macrogland secretions in South American toads: a preliminary biochemical delineation. Scient World J 2013, 2013(2013):1-9. doi:10.1155/2013/937407.

14. Costa TO, Morales RA, Brito JP, Gordo M, Pinto AC, Blosh C Jr: Occurrence of bufotenin in the Osteocephalus genus (Anura: Hylidae). Toxicon 2005, 46(4):371-375 
15. Smith TA: Tryptamine and related compounds in plants. Phytochemistry 1977, 16(2):171-175.

16. Stromberg VL: The isolation of bufotenine from Piptadenia peregrina. J Am Chem Soc 1954, 76(6):1707.

17. Batista AM, Cruz PS, Almeida E, Costa AEB, Scheffer KC, Chaves LB, Silva ACR, Medeiros Caporale GM: Infection of BHK-21 cells cultivated in stationary monolayers by PV and CVS strains. Bol Epidemiol Paul (Online) 2009, 6(71):4-11.

18. Takeuchi H, Baba M, Shigeta S: An application of tetrazolium (MTT) colorimetric assay for the screening of anti-herpes simplex virus compounds. J Virol Methods 1991, 33(1-2):61-71.

19. Mosmann T: Rapid colorimetric assay for cellular growth and survival: application to proliferation and cytotoxicity assays. J Immunol Methods 1983, 65(1-2):55-63.

20. Flores EF, Editor: Vírus da raiva e lyssavirus relacionados. In Virologia Veterinária. Rio Grande do Sul: UFSM; 2007:700-711.

21. Favoretto SR, Carrieri ML, Tino MS, Zanetti CR, Pereira AO: Simplified fluorescent inhibition microtest for the titration of rabies neutralizing antibodies. Rev Inst Med Trop São Paulo 1993, 35(2):171-175.

22. Lockhart BP, Tordo $\mathrm{N}$, Tsiang $\mathrm{H}$ : Inhibition of rabies virus transcription in rat cortical neurons with the dissociative anesthetic ketamine. Antimicrob Agents Chemother 1992, 36(8):1750-1755.

23. Smith JS, Yager PA, Baer GM: A rapid reproducible test for determining rabies neutralizing antibody. Bull World Health Organ 1973, 48(5):535-541.

24. Chaves LB, Mazutti ALC, Medeiros Caporale GM, Scheffer KC, Silva ACR: Comparision of RFFIT performed in lab-tek ${ }^{\circledast}$ and in 96-well microtitre plates. In RITA XVII. Annales of the XVII International Conference on Rabies in the Americas: 15-20 octuber, 2006; Brasília, Brazil. Brasília: Ministério da Saúde; 2006:161.

25. Medeiros Caporale GM, Rodrigues Da Silva A, De C, Peixoto ZM, Chaves LB, Carrieri ML, Vassao RC: First production of fluorescent antiribonucleoproteins conjugate for diagnostic of rabies in Brazil. J Clin Lab Anal 2009, 23(1):7-13.

26. McClean S, Robinson RC, Shaw C, Smyth WF: Characterisation and determination of indole alkaloids in frog-skin secretions by electrospray ionisation ion trap mass spectrometry. Rapid Commun Mass Spectrom 2002, 16(5):346-354.

27. Handovsky H: Ein Alkaloid im Gifte von Bufo vulgaris. Arch Exp Pathol Pharmakol 1920, 86(1-2):138-158

28. Blom JD: A Dictionary of Hallucinations. New York: Springer-Verlag; 2010:79-80.

29. Prates I, Antoniazzi MM, Sciani JM, Pimenta DC, Toledo LF, Haddad CF, Jared C: Skin glands, poison and mimicry in dendrobatid and leptodactylid amphibians. J Morpho/ 2012, 273(3):279-290.

30. Sousa JC, Berto RF, Gois EA, Fontenele-Cardi NC, Honório JE Jr, Konno K, Richardson M, Rocha MF, Camargo AA, Pimenta DC, Cardi BA, Carvalho KM: Leptoglycin: a new Glycine/Leucine-rich antimicrobial peptide isolated from the skin secretion of the South American frog Leptodactylus pentadactylus (Leptodactylidae). Toxicon 2009, 54(1):23-32.

31. Tempone AG, Pimenta DC, Lebrun I, Sartorelli P, Taniwaki NN, De Andrade $H F$, Jr AMM, Jared C: Antileishmanial and antitrypanosomal activity of bufadienolides isolated from the toad Rhinella jimi parotoid macrogland secretion. Toxicon 2008, 52(1):13-21.

32. Evarts EV, Landau W, Freygang W Jr, Marshall WH: Some effects of lysergic acid diethylamide and bufotenine on electrical activity in the cat's visual system. Am J Physiol 1955, 182:594-598.

33. Harley-Mason J, Jackson AH: A new synthesis of bufotenine. Chem Ind 1952, 39:954.

34. Wieland $\mathrm{H}$, Konz W, Mittasch $\mathrm{H}$ : Die konstitution von Bufotenin und Bufotenidin. Über kröten-Giftstoffc. VII. Justus Liebigs Ann Chem 1934 513(1):1-25

35. Santos JS, Marinho RR, Ekundi-Valentim E, Rodrigues L, Yamamoto MH, Teixeira SA, Muscara MN, Costa SK, Thomazzi SM: Beneficial effects of Anadenanthera colubrina (Vell.) Brenan extract on the inflmmatory and nociceptive responses in rodent models. J Ethnopharmacol 2013, 148(1):218-222.

36. Da Silva LC, Sandes JM, Paiva MM, De Araújo JM, De Figueiredo RC, Da Silva MV, Correia MT: Anti-Staphylococcus aureus action of three Caatinga fruits evaluated by electron microscopy. Nat Prod Res 2012, 27(16):1492-1496. doi:10.1080/14786419.2012.722090.

37. Pessoa WS, Estevão LRM, Simões RS, Barros MEG, De Mendonça F S, BaratellaEvêncio L, Evêncio-Neto J: Effects of angico extract (Anadenanthera colubrina var. cebil) in cutaneous wound healing in rats. Acta Cir Bras 2012 27(10):655-670.
38. Fabing HD, Hawkins Jr: Intravenous bufotenine injection in the human being. Science 1956, 123(3203):886-887.

39. Raymond-Hamet M: Sur les effects tenseurs et respiratoires de la bufoténine basique dissolute dans le diméthyl-acétonyl-carbinol. Seances Acad Sci 1944, 218:54-56.

40. Raymond-Hamet M: Sur les effets vasculaires de la bufoténine introduite dans la circulation générale. CR Hebd Seances Acad Sci 1942, 214:506-508. Available at: http://gallica.bnf.fr/ark:/12148/bpt6k3166b/f506.

41. Stefani HA, Vasconcelos SNS, Souza FB, Manarin F, Zukerman-Sphector J: One-pot three-component synthesis of indole-3-glyoxyl derivatives and indole-3-glyoxyl triazoles. Tetrahedron Lett 2013, 54(43):5821-5825.

doi:10.1186/1678-9199-20-45

Cite this article as: Vigerelli et al:: Bufotenine is able to block rabies virus infection in BHK-21 cells. Journal of Venomous Animals and Toxins including Tropical Diseases 2014 20:45.

\section{Submit your next manuscript to BioMed Central and take full advantage of:}

- Convenient online submission

- Thorough peer review

- No space constraints or color figure charges

- Immediate publication on acceptance

- Inclusion in PubMed, CAS, Scopus and Google Scholar

- Research which is freely available for redistribution 